\title{
Electrical Power Problem
}

National Cancer Institute

\section{Source}

National Cancer Institute. Electrical Power Problem. NCI Thesaurus. Code C63217.

Problem associated with the quality of the facility-supplied power to the device. 